Огляди літератури, оригінальні дослідження, погляд на проблему, ювілеї

УДК 616.37-002.2:616.12-008.331.1:616-008.9:577.118

DOI 10.11603/1811-2471.2019.v0.i1.10044

\title{
РОЗЛАДИ СИСТЕМИ МІКРОЕЛЕМЕНТІВ У ХВОРИХ НА ХРОНІЧНИЙ ПАНКРЕАТИТ У ПОЄДНАННІ 3 ГІПЕРТОНІЧНОЮ ХВОРОБОЮ
}

\author{
๑Е. Й. Архій, Л. Б. Прилипко, Б. М. Галай \\ ДВНЗ «Ужгородський національний університет»
}

РЕЗЮМЕ. Рівновага у системі мікроелементів $\epsilon$ важливою для нормального функціонування усіх органів та систем. Наявність тих чи інших патологічних змін сприяє появі або ж прогресуванню розладів у цій налагодженій системі. Не $є$ винятком і хронічний панкреатит (ХП) та гіпертонічна хвороба (ГХ).

Мета дослідження - визначити зміни мікроелементного складу крові у хворих на ХП у поєднанні з ГХ.

Матеріал і методи. Для досягнення поставленої мети ми обстежили 102 хворих на ХП та ГХ II стадії (основна група) та 23 практично здорових осіб (контрольна група). Крім загальноклінічного обстеження визначали концентрацію натрію, кальцію, калію, хлору, селену та цинку у плазмі крові та досліджували екзокринну функцію підшлункової залози (ПЗ) за рівнем фекальної еластази-1 (ФЕ-1).

Результати. У пацієнтів основної групи було виявлено зниження концентрації кальцію (до $(2,16 \pm 0,26)$ ммоль/л проти $(2,47 \pm 0,18)$ ммоль/л у групі практично здорових осі6, p<0,01), селену (до $(63,68 \pm 18,47)$ мкг/л на противагу $(88,16 \pm 15,71)$ мкг/л у осі6 II групи $(p=0,61)$ ти цинку (до $(741,05 \pm 202,47)$ мкг/л проти $(956,24 \pm 172,31)$ мкг/л у обстежених контрольної групи) ( $p=0,20)$. Рівні інших досліджуваних нами мікроелементів не виходили за межі референтних величин. При вивченні функціональної спроможності було діагностовано зовнішньосекреторну недостатність ПЗ на межі легкого та помірного ступеня $((157,82 \pm 17,28)$ мкг/г калу).

Висновки. Діагностовані зміни у складі мікроелементів потребують корекції з метою досягнення гомеостазу в організмі і запобігання прогресуванню та розвитку ускладнень ХП та ГХ.

КЛючОВІ СлОВА: хронічний панкреатит; гіпертонічна хвороба; дисбаланс мікроелементів.

Вступ. Підшлунковій залозі (ПЗ) належить унікальна роль у забезпеченні життєдіяльності організму людини - вона виконує екзокринну та ендокринну функції, беручи участь у забепеченні гомеостазу всього організму. Дисфункції Пз можуть призводити як до порушень травлення (зміна шлунково-кишкової секреції, абсорбції, моторики), так і до генералізованих метаболічних змін [1]. Хронічний панкреатит (ХП) є одним із провідних захворювань ПЗ, яке розглядається сьогодні як прогресуюче поліетіологічне запальне ураження тканини ПЗ, що супроводжується розвитком її зовнішньо- та внутрішньосекреторної недостатності. ХП характеризується персистенцією запального інфільтрату, прогресуючим руйнуванням ациноцитів та фіброзом, що в кінцевому результаті спричиняє руйнування тканини залози [2].

Зазвичай хронічний запальний процес у тканині ПЗ не $\epsilon$ ізольованим, досить частим поєднанням $€$ хронічний панкреатит та гіпертонічна хвороба (ГХ). Поява обох патологічних станів пов'язана не лише із значною поширеністю, а й зумовлена i спільними етіологічними чинниками: куріння, зловживання алкоголем, хронічний стрес, зміна харчування [3]. Поєднання патологій змінює перебіг обох захворювань, що вимагає від усіх учасників медичної наукової спільноти посиленого пошуку можливих етіопатогенетичних механізмів коморбідних станів з подальшою розробкою специфічних та дієвих методів профілактики і лікування.
Нашу увагу привернули зміни у системі мікроелементів у хворих на ХП та ГХ. Рівновага у роботі цієї системи є однією із важливих ланок підтримки гомеостазу людського організму, оскільки саме мікроелементи $\epsilon$ структурними компонентами не менше ніж 2000 ферментів, що каталізують різноманітні життєво важливі хімічні реакції організму [4]. Загалом, надлишок або нестача тих чи інших мікроелементів сприяє зниженню опірності організму, послаблює антиоксидантний захист в умовах "оксидативного стресу", зумовлює виникнення імунодефіцитних станів, що в кінцевому результаті сприяє хронізації патологічних змін. Крім того, зміна мікроелементного гомеостазу погіршує якість життя пацієнтів та знижує ефективність призначених схем терапії [5]. Дисбаланс мікроелементного складу приводить до зміни функціонування на рівні клітини, що необхідно враховувати при виборі тактики лікування. Тож своєчасна і ефективна корекція мікроелементозів дає можливість істотно змінювати показники здоров'я у сторону позитивної динаміки.

ХП розглядається як фактор, що сприяє появі дисбалансу мікроелементного складу або ж як наслідок існуючого, а ГХ - частіше як результат останнього. Внаслідок наявності зовнішньосекреторної недостатності різного ступеня при ХП з часом розвиваються мальабсорбція, мальдигестія та, у подальшому, мальнутриція. Саме при панкреатичній мальдигестії значних змін зазнає мінеральний обмін: спостерігається зниження рів- 
Огляди літератури, оригінальні дослідження, погляд на проблему, ювілеї

ня кальцію (Са), калію (K), натрію (Na), заліза (Fe), цинку (Zn), селену (Se), магнію (Mg) та ряду інших мікроелементів [6]. Існуючий дефіцит мікроелементів сприяє появі дисбалансу у системі антиоксидантного захисту, що призводить до активації перекисного окиснення ліпідів. Наслідком останнього процесу $є$ поява оксидативного стресу, який сприяє виникненню запальних змін на рівні різних органів і систем. Не $є$ винятком і ендотелій судинної стінки.

Так, Макарова Т. П. (2018) зазначає, що одним із важливих механізмів розвитку ендотеліальної дисфункції, яка відіграє важливу роль у еволюції ГХ, є зміна мікроелементного гомеостазу [7]. Бабінець Л. С. та співавт. (2016) теж вказують на провідну роль у розвитку ХП активації процесів ліпопероксидації, однією із причин якої $\epsilon$ мікроелементози [8].

3 огляду на наведені факти наукових досліджень, ми вважаємо за доцільне продовжити вивчення впливу змін гомеостазу мікроелементів на появу та перебіг поєднаної патології ХП та ГХ.

Мета дослідження - виявити особливості мінерального обміну у хворих на хронічний панкреатит у поєднанні з гіпертонічною хворобою.

Матеріал і методи дослідження. Для досягнення встановленої мети ми сформували основну та контрольну групи. До основної групи було включено 102 хворих на ХП та ГХ ІІ стадії, які перебували на стаціонарному лікуванні у терапевтичному відділенні Хустської районної лікарні протягом 2017-2018 років. Групу контролю склали 23 практично здорових особи. Усім було проведене загальноклінічне (збір скарг, анамнезу захворювання та життя, об'єктивне обстеження), лабораторне (загальний аналіз крові та сечі, біохімічне дослідження крові, копроскопія, дослідження рівня ФЕ-1) та інструментальне дослідження (ультразвукове обстеження органів черевної порожнини, електрокардіографія). Середній вік хворих

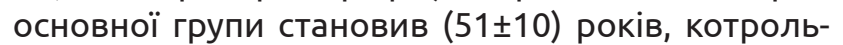

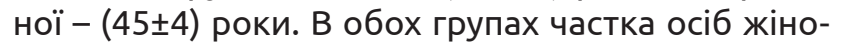
чої статі дещо переважала частку обстежених чоловіків (у основній групі - 56 \% проти 44 \% та у контрольній - $67 \%$ проти $33 \%$ ).

Діагноз ХП верифікували відповідно до вимог наказу МОЗ України № 638 від 10.09.2014 "Уніфікований клінічний протокол первинної, вторинної (спеціалізованої) медичної допомоги та медичної реабілітації. Хронічний панкреатит". Встановлення діагнозу ГХ базувалося на вимогах клінічних рекомендацій з артеріальної гіпертензії Європейського товариства гіпертензії (ESH) і Європейського товариства кардіологів (ESC) (2013р.) та наказу МО3 України № 384 від 24 травня 2012 року “Уніфікований клінічний протокол пер- винної, екстреної та вторинної (спеціалізованої) медичної допомоги. Артеріальна гіпертензія".

Усі пацієнти були поінформовані про комплекс діагностично-лікувальних заходів і дали інформовану згоду на участь у дослідженні.

Для визначення показників стану мінерального обміну проводилося дослідження крові. Забір матеріалу здійснювали протягом 24 годин після госпіталізації. При визначенні вмісту мікроелементів у плазмі крові хворих на ХП у поєднанні з ГХ було вжито кілька методик:

- для вимірювання концентрації калію (K) турбідиметричний метод без депротеїнування;

- натрію (Na) - колориметричний метод 3 фосфоназою III;

- кальцію (Са) - фотометричний метод з арсеназою III;

- хлору (Cl) - фотометричний метод;

- селену (Se) - спектрофлуориметрія після "мокрої" мінералізації проби;

- цинку (Zn) - електротермічна атомно-а6сорбційна спектроскопія.

3 метою встановлення екзокринної спроможності ПЗ досліджували рівень фекальної еластази-1 (ФЕ-1) за допомогою імуноферментного аналізу ELISA (Pancreatic Elastase 1 Stool Test) із діагностичним тестовим набором (виробник - ScheBo Biotech AG, Німеччина).

Вимірювання артеріального тиску (АТ) здійснювали відповідно до загальноприйнятої методики аускультації тонів за Н. С. Коротковим.

Статистичну обробку отриманих результатів виконано з використанням комп'ютерної програми "Statistica for Windows" 10,0 версії.

Результати й обговорення. Після первинного обстеження у всіх пацієнтів основної групи було встановлено больовий, диспептичний, астеноневротичний синдроми, синдром зовнішньосекреторної недостатності ПЗ (ЗНПЗ) та артеріальної гіпертензії (АГ). У 100 \% хворих переважали больовий та астеноневротичний синдроми. Такі синдроми як диспептичний, синдром ЗНПЗ та АГ по-різному проявлялися у обстежуваних досліджуваної групи.

При збиранні анамнезу захворювання встановлено, що тривалість ХП становила $(7 \pm 3)$ роки,

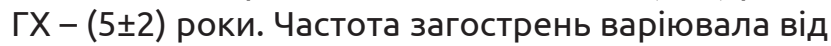
1 до 4 разів на рік. Так, частка пацієнтів із загостренням ХП 1-2 рази на рік складала 67,6 \%, 2-3 рази на рік - 28,4 \%, 3-4 рази на рік - 5,9\%. Можна стверджувати, що основу обстеженого контингенту становили пацієнти з клінічним перебігом ХП середнього та легкого ступенів тяжкості. Останні результати відповідали отриманим даним при дослідженні рівня еластази-1 у калі у хворих основної групи (табл. 1). 
Огляди літератури, оригінальні дослідження, погляд на проблему, ювілеї

Таблиця 1. Рівень фекальної еластази-1

\begin{tabular}{|l|c|c|c|}
\hline \multicolumn{1}{|c|}{ Показник } & $\begin{array}{c}\text { Основна група } \\
(\mathrm{n}=102)\end{array}$ & $\begin{array}{c}\text { Контрольна група } \\
(\mathrm{n}=23)\end{array}$ & $\begin{array}{c}\text { Рівень статистичної значимості } \\
\text { відмінності між групами (p) }\end{array}$ \\
\hline $\begin{array}{l}\text { Фекальна еластаза-1 } \\
\text { (>200 мкг/г калу) }\end{array}$ & $157,82 \pm 17,28$ & $203,47 \pm 13,64$ & $<0,01$ \\
\hline
\end{tabular}

Як видно з таблиці, у хворих на ХП у поєднанні з ГХ ІІ стадії спостерігається достовірне зниження функціональної спроможності ПЗ у порівнянні із практично здоровими особами. І рівень екзо- кринної недостатності у цих пацієнтів знаходиться на межі помірного та легкого ступенів тяжкості.

Досліджуючи мінеральний обмін ми отримали результати, які відтворені у таблиці 2.

Таблиця 2. Рівень мікроелементів у крові хворих на хронічний панкреатит у поєднанні з гіпертонічною хворобою ІІ стадії

\begin{tabular}{|c|c|c|c|}
\hline Мікроелементи & $\begin{array}{c}\text { Основна група } \\
(\mathrm{n}=102)\end{array}$ & $\begin{array}{c}\text { Контрольна група } \\
(\mathrm{n}=23)\end{array}$ & $\begin{array}{c}\text { Рівень статистичної } \\
\text { значимості відмінності } \\
\text { між групами (р) }\end{array}$ \\
\hline $\begin{array}{c}\mathrm{Na} \\
(135-155, \text { ммоль/л) }\end{array}$ & $143,08 \pm 3,14$ & $141,94 \pm 4,18$ & 0,14 \\
\hline $\begin{array}{c}\text { Са } \\
(2,1-2,6, \text { ммоль/л) }\end{array}$ & $2,16 \pm 0,26$ & $2,47 \pm 0,18$ & 0,15 \\
\hline $\begin{array}{c}\mathrm{K} \\
(3,6-5,5, \text { ммоль/л) }\end{array}$ & $4,38 \pm 0,38$ & $4,51 \pm 0,41$ & 0,30 \\
\hline $\begin{array}{c}\text { Сl } \\
(95-108, \text { ммоль/л) }\end{array}$ & $101,93 \pm 3,11$ & $102,72 \pm 4,05$ & $<0,01$ \\
\hline $\begin{array}{c}\text { Zп } \\
(543-1130, \text { мкг/л) }\end{array}$ & $741,05 \pm 202,47$ & $956,24 \pm 172,31$ & $<0,01$ \\
\hline $\begin{array}{c}\text { Sе } \\
(23-190, \text { мкг/л) }\end{array}$ & $63,68 \pm 18,47$ & $88,16 \pm 15,71$ & \\
\hline
\end{tabular}

Аналізуючи отримані результати, ми бачимо, що концентрація $\mathrm{Na}, \mathrm{K}, \mathrm{Cl}$ у крові пацієнтів основної групи не виходить за межі референтних величин та достовірна відмінність із цими ж показниками контрольної групи відсутня. Це дозволяє нам вказувати на відсутність змін у метаболізмі даних мікроелементів при поєднаній патології ХП та ГХ. Щодо вмісту Са, та багато науковців описують зниження його рівня у крові при ХП. Наші результати вказують на те, що вміст останнього мікроелемента знаходиться на нижній межі норми у пацієнтів основної групи - $(2,16 \pm 0,26)$ ммоль/л проти $(2,47 \pm 0,18)$ ммоль/л у групі практично здорових осіб $(p<0,01)$. Оскільки у обстежуваних хворих на ХП та ГХ ІІ стадії відповідно до рівня ФЕ-1 встановлено ЗНПЗ легкого та середнього ступенів, то можна припустити, що при прогресуванні захворювання рівень Са буде й далі знижуватися. Рівновага цього мікроелемента $\epsilon$ надзвичайно важливою для злагодженої роботи ПЗ. Адже саме Са бере участь у синтезі та екскреції ферментів ПЗ. Крім того, він може змінювати функцію панкреатичних клітин, стимулюючи виділення ацетилхоліну з нервових закінчень [9]. Концентрація кальцію відіграє немалу роль і у регуляції судинного тонусу. Доведено, що рівень ендотеліальної NO-синтетази корелює з рівнем Ca, а саме, ендо- теліальна NO-синтетаза забезепечує сталий необхідний рівень одного з основних судинорозширювальних чинників - оксиду азоту [10].

Рівень мікроелементів Zn i Se $\epsilon$ зниженим, а саме, Se - у основній групі - до $(63,68 \pm 18,47)$ мкг/л (у контрольній $-(88,16 \pm 15,71)$ мкг/л $(p=0,61)) ; Z n-y$ І групі - (741,05 202,47$)$ мкг/л (у || - $(956,24 \pm$ $172,31)$ мкг/л $(p=0,20))$. Важливим елементом дослідження було виявлення сильного позитивного кореляційного зв'язку між концентраціями вказаних мікроелементів у крові хворих на ХП у поєднанні з ГX II стадії $(r=0,63, p<0,01)$. Крім цього, виявлено помірну позитивну кореляцію між рівнями Se i Ca $(r=0,44, p<0,01)$ та вмістом $Z n$ i Ca $(r=0,39$, $p<0,01)$, що відповідає результатам інших науковців. Буклис Э. Р. стверджує, що недостатність Zn сприяє пошкодженню ацинарних клітин та гальмує синтез як бікарбонатів, так і панкреатичних протеаз, i цим стимулює прогресування екзокринної недостатності ПЗ [11]. Дисбаланс цинку спричиняє також появу серцево-судинних захворювань, до яких належить і ГX [12]. А дефіцит Sе провокує дегенерацію та фіброз тканини ПЗ й сприяє дистрофії міокарда та розвитку серцевої недостатності.

При аналізі отриманих нами результатів чітко прослідковується збій у гомеостазі певних мікроелементів у крові пацієнтів основної групи. Наслід- 
Огляди літератури, оригінальні дослідження, погляд на проблему, ювілеї

ком цього $\epsilon$ формування так званого "замкненого кола", яке сприяє прогресуванню, хронізації та формуванню ускладнень як для перебігу ХП, так і ГХ.

Висновки. 1. Поєднання захворювань ХП та ГХ характеризується наявністю дисбалансу мікроелементного складу крові.

2. У досліджуваного контингенту пацієнтів виявлено гіпокальціємію, гіпоселенемію та гіпоцинкемію.

3. Зважаючи на те, що дотримання рівноваги цих мікроелементів відіграє важливе значення для повноцінної роботи підшлункової залози та регуляції судинного тонусу, вважаємо доречним доповнення базової терапії обох патологій додатковим введенням кальцію, селену та цинку.

Перспективи подальших досліджень передбачають вивчення функціональної спроможності підшлункової залози та регуляції артеріального тиску у хворих на ХП у поєднанні з ГХ після досягнення референтних величин досліджуваних нами мікроелементів.

\section{ЛІТЕРАТУРА}

1. Ройтберг Г. Е. Внутренние болезни. Печень, желчевыводящие пути, поджелудочная железа : учеб. пособие / Г. Е. Ройтберг, А. В. Струтынский. - 3-е изд. М. : МЕДпресс-информ, 2016. - 637 с.

2. Yang D. Chronic pancreatitis / D. Yang, C. E. Forsmark // Curr. Opin. Gastroenterol. -2017. - Vol. 33, No. 5. - P. 396-403.

3. Пасієшвілі Л. М. Асоціація метаболічних і генетичних маркерів ризику розвитку остеопенічних станів при поєднанні хронічного панкреатиту і гіпертонічної хвороби / Л. М. Пасієшвілі, Т. І. В'юн, О. А. Лазуткіна // Здобутки клінічної і експериментальної медицини. 2018. - № 2. - С. 81-85.

4. Скальный А. В. Химические элементы в физиологии и экологии человека / А. В. Скальный. - М. : Мир, 2004. - 216 c.

5. Канжигалина 3. К. Биологическая роль и значение микроелементов в жизнедеятельности человека / 3. К. Канжигалина, Р. К. Касенова, А. Ш. Орадова // Вестник КазНМУ. - 2013. - № 5 (2). - С. 88-90.

6. Губергриц Н. Б. Панкреатология и “скелет в шкафу" / Н. Б. Губергриц., П. Г. Фоменко // Новини медицини та фармації. Гастроентерология. - 2012. - № 434.

7. Макарова Т. П. Эндотелиальная дисфункция и элементный статус при хронической болезни почек у

\section{REFERENCES}

1. Roytberg, G.E., \& Strutynskiy, A.V. (2016). Vnutrennye bolezny. Pechen, zhelchevyvodyashchye puti, podzheludochnaya zheleza: ucheb. posobye [Internal illnesses. Liver, biliary tract, pancreas: guide]. Moscow: MEDpressinform [in Russian].

2. Yang, D., \& Forsmark, C.E. (2017). Chronic pancreatitis. Curr. Opin. Gastroenterol., 5, 396-403.

3. Pasiieshvili, L.M., Viun, T.I., \& Lazutkina, O.A. (2018). Asotsiatsiia metabolichnykh i henetychnykh markeriv ryzyku rozvytku osteopenichnykh staniv pry poiednanni khronichnoho pankreatytu i hipertonichnoi khvoroby [Association of metabolic and genetic markers of the risk of developing osteopenic states in combination of chronic pancreatitis and hypertension]. Zdobutky klinichnoi $i$ eksperymentalnoi medytsyny - The Achievements of Clinical and Experimental Medicine, 2, 81-85 [in Ukrainian]. детей / Т. П. Макарова, Ю. С. Мельникова // Российский вестник перинатологии и педиатрии. -2018. - № 63 (2). C. $48-52$.

8. Бабінець Л. С. Патогенетичні аспекти клінічного перебігу хронічного панкреатиту: роль про- і антиоксидантного статусу / Л. С. Бабінець, І. М. Галабіцька // Здоров'я України. - 2016. - № 1 (39). - С. 49-51.

9. Пасієшвілі Л. М. Роль кальцію у формуванні клініко-лабораторних синдромів при різних варіантах хронічного панкреатиту / Л. М. Пасієшвілі, М. В. Моргуліс // Сучасна гастроентерологія. - 2006. - № 4 (30). С. 31-34.

10. Ендотеліальна дисфункція та артеріальна гіпертензія / С. В. Білецький, В.В.Бойко, О. А. Петринич, Т. В. Казанцева // Клінічна та експериментальна патологія. - 2017. - № 1 (59). T. XVI. - С. 160-163.

11. Буклис Э. Р. Трофологическая недостаточность при болезнях органов пищеварения / Э. Р. Буклис // Клинические перспективы гастроэнтерологии, гепатологии. - 2004. - № 2. - С. 10-15.

12. Kim J. Dietary zinc intake is inversely associated with systolic blood preasure in young obese women / J. Kim // Nutrition Research and Practice. -2013. - No. 7(5).P. 380-384. 
Огляди літератури, оригінальні дослідження, погляд на проблему, ювілеї

koy bolezni pochek $u$ detey [Endothelial dysfunction and elemental status in chronic kidney disease in children]. Rossiyskiy vestnik perinatologii i pediatrii - Russian Journal of Perinatology and Pediatrics, 63 (2), 48-52 [in Ukrainian].

8. Babinets, L.S., \& Halabitska, I.M. (2016). Patohenetychni aspekty klinichnoho perebihu khronichnoho pankreatytu: rol pro- i antyoksydantnoho statusu [Pathogenetic aspects of the clinical course of chronic pancreatitis: the role of pro- and antioxidant status]. Zdorovia Ukrainy Health of Ukraine, 1 (39), 49-51 [in Ukrainian].

9. Pasiieshvili, L.M., \& Morhulis, M.V. (2006). Rol kaltsiiu u formuvanni kliniko-laboratornykh syndromiv pry riznykh variantakh khronichnoho pankreatytu [The role of calcium in the formation of clinical and laboratory syndromes in various variants of chronic pancreatitis]. Suchasna hastroenterolohiia - Modern Gastroenterology, 4 (30),
31-34 [in Ukrainian].

10. Biletskyi, S.V., Boiko, V.V., Petrynych, O.A., \& Kazantseva, T.V. (2017). Endotelialna dysfunktsiia ta arterialna hipertenziia [Endothelial dysfunction and arterial hypertension]. Klinichna ta eksperymentalna patolohiia Clinical and Experimental Pathology, 1 (59), 160-163 [in Ukrainian].

11. Buklis, E.R. (2004). Trofologicheskaya nedostatochnost pri boleznyakh organov pishchevareniya [Trophological deficiency in diseases of the digestive system]. Klinicheskiye perspektivy gastroenterologii, gepatologii Clinical Perspectives of Gastroenterology, Hepatology, 2, 10-15 [in Russian].

12. Kim, J. (2013). Dietary zinc intake is inversely associated with systolic blood preasure in young obese women. Nutrition Research and Practice, 7 (5), 380-384.

\title{
РАССТРОЙСТВА СИСТЕМЫ МИКРОЭЛЕМЕНТОВ У БОЛЬНЫХ С ХРОНИЧЕСКИМ ПАНКРЕАТИТОМ В СОЧЕТАНИИ С ГИПЕРТОНИЧЕСКОЙ БОЛЕЗНЬЮ
}

\author{
๑э. Й. Архий, Л. Б. Прилипко, Б. М. Галай \\ ГУВЗ «Ужгородский национальный университет»
}

РЕЗЮМЕ. Равновесие в системе микроэлементов является важным элементом нормального функционирования всех органов и систем. Наличие тех или иных патологических изменений способствуєт появлению или прогрессированию расстройств в этой отлаженной системе. Не являются исключением хронический панкреатит (ХП) и гипертоническая болезнь (ГБ). с ГБ.

Цель исследования - определить изменения микроэлементного состава крови у больных ХП в сочетании

Материал и методы. Для достижения поставленной цели мы обследовали 102 больных ХП и ГБ ІІ стадии (основная группа) и 23 практически здоровых лиц (контрольная группа). Кроме общеклинического обследования, определяли концентрацию натрия, кальция, калия, хлора, селена и цинка в плазме крови и исследовали экзокринную функцию поджелудочной железы (ПЖ) по уровню фекальной еластазы-1 (ФЕ-1).

Результаты. У пациентов основной группы было выявлено снижение концентрации кальция (до (2,16士

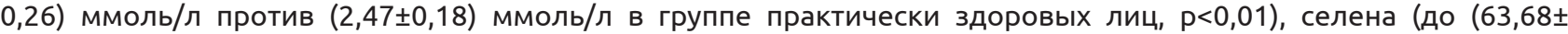
$18,47)$ мкг/л в противовес $(88,16 \pm 15,71)$ мкг/л у лиц II группы $(p=0,61)$ и цинка $(д о ~(741,05 \pm 202,47)$ мкг/л против $(956,24 \pm 172,31)$ мкг/л у обследованных контрольной группы $(p=0,20)$. Уровни других исследуемых нами микроэлементов не выходили за пределы референтных величин. При исследовании функциональной способности Пж была диагностирована ее внешнесекреторная недостаточность на грани легкой и умеренной степени $((157,82 \pm 17,28)$ мкг/г кала).

Выводы. Диагностированные изменения в составе микроэлементов требуют коррекции с целью достижения гомеостаза в организме и предупреждения прогрессирования и развития осложнений ХП и ГБ.

КЛЮчЕВЫЕ СЛОВА: хронический панкреатит; гипертоническая болезнь; дисбаланс микроэлементов.

\section{DISORDERS OF THE SYSTEM OF MICROELEMENTS IN PATIENTS WITH CHRONIC PANCREATITIS IN COMBINATION WITH HYPERTENSION}

\author{
@E. J. Arkhij, L. B. Prilipko, B. M. Halay \\ Uzhhorod National University
}

SUMMARY. Equilibrium in the system of microelements is an important element of the normal functioning of all organs and systems. Of course, the presence of certain pathological changes contributes to the emergence or progression of disorders in this well-established system. Chronic pancreatitis (CP) and hypertonic disease (HD) are not exception.

The aim of the study - to determine the changes in the microelement composition of blood of patients with $\mathrm{CP}$ in conjunction with HD.

Material and Methods. To achieve this goal, we examined 102 patients with CP and HD (main group) and 23 practically healthy patients (control group). In addition to the general clinical trial, the concentration of natrium, calcium, 
Огляди літератури, оригінальні дослідження, погляд на проблему, ювілеї

kalium, chlorine, selenium and zincum in blood plasma was determined and the exocrine function of the pancreas (P) was measured for fecal elastase-1 (FE-1) levels.

Results. The patients of the main group had decreased calcium concentration to $(2.16 \pm 0.26) \mathrm{mmol} / \mathrm{l}$ against $(2.47 \pm 0.18) \mathrm{mmol} / \mathrm{l}$ in the group of practically healthy persons, $\mathrm{p}<0.01)$, selenium - up to $(63.68 \pm 18.47) \mathrm{mcg} / \mathrm{l}$, as opposed to $(88.16 \pm 15.71) \mathrm{mcg} / \mathrm{l}$ in group II $(p=0.61)$ zincum - up to $(741.05 \pm 202.47) \mathrm{mcg} / \mathrm{l}$ versus $(956.24 \pm 172.31) \mathrm{mcg} / \mathrm{l}$ in the examined control group ( $p=0.20)$. The levels of other microelements studied by us did not go beyond the reference values. In the study of functional capacity, external-secretion insufficiency of the pancreas at the border of the lung and moderate degree was diagnosed ((157.82 \pm 17.28$) \mathrm{mcg} / \mathrm{g}$ faeces).

Conclusions. Diagnosed changes in the composition of microelements require correction in order to achieve homeostasis in the body and prevent the progression and development of complications of CP and HD.

KEY WORDS: chronic pancreatitis; hypertonic disease; imbalance of microelements.

Отримано 21.11.2018 